\title{
Utilization of Puskesmas in Efforts to Prevent COVID-19 in Bengkulu City
}

Oktarianita*, Andry Sartika, Nopia Wati, Bintang Agustina Pratiwi

Public Health Department, Faculty of Health Sciences, Universitas Muhammadiyah Bengkulu, Indonesia

*corresponding author, email: oktarianita@umb.ac.id

\section{ARTICLE INFO}

Article history

Received 21/07/21

Revised 04/09/21

Accepted 22/09/21

Keywords

Utilization;

Covid-19 prevention

Health center;

Puskesmas

\section{ABSTRACT}

Background: Puskesmas as First Level Health Facilities (FKTP) plays a vital role during the Covid-19 pandemic in preventing and controlling the number of Covid-19 cases by anticipating, detecting, responding to events. However, at this time, the puskesmas are still underutilized by the community. The highest confirmed positive cases in Bengkulu City were in the Gading Cempaka District, with 990 cases. This study aimed to determine the variables related to the utilization of puskesmas in Bengkulu City. Methods: This research was quantitative research with a cross-sectional study design. Data collection was carried out by distributing questionnaires to respondents using an accidental sampling technique executed in March-August 2021. The research population was the entire community of Bengkulu City, with a sample of 110 respondents from the Gading Cempaka District, Bengkulu City. Data were analyzed by univariate to multivariate logistic regression. Results: The results show that 88 respondents $(78.2 \%)$ have utilized the puskesmas, as many as $86(78.2 \%)$ were female, 86 respondents (60.9\%) belonged to the young age group, respondents with higher education were 73 respondents ( $66.4 \%), 73$ respondents $(66.4 \%)$ worked and as many as 79 respondents $(71.8 \%)$ have income <UMP. The bivariate analysis results showed that the factors related to the utilization of the puskesmas $(p<0.05)$ were variables of age, education, occupation, and income despite no relationship between gender, distance, knowledge, and family support $(p>\alpha)$. The results of the multivariate analysis showed that education was the dominant factor influencing the utilization of the puskesmas with ( $\mathrm{p}$-value $=0.010 ; \mathrm{B}=2.707 ; 95 \% \mathrm{Cl}=1.892$ 118.569). Conclusion: The community has taken advantage of the puskesmas in terms of preventing Covid-19. The utilization of puskesmas is affected by age and education level.

This is an open access article under the CC-BY-SA license.

\section{Introduction}

Cases of Corona Virus Disease-19 (Covid-19) in Indonesia continue to increase from 59,394 cases in August 2020-2021 to reach 4,043,736 cases with 113,664 deaths [2]. Data obtained from the latest situation on the development of Covid- 19 cases confirmed 6,275 positive cases of Covid-19 in the city of Bengkulu in 2021. The suspected is also cases increased from 2,212 to 7,759 in 2021. Preliminary studies showed that as many as 990 positive cases of Covid-19 were in the Gading Cempaka District. Meanwhile, suspected cases of Covid-19 in 2020 have increased to 1,939 cases [3].

Health services determine the level of public health, and puskesmas is one of the targets. Puskesmas is a functional unit that is the center of community health development and fosters 
community participation by providing comprehensive and integrated services to all levels of society in its working area. In Indonesia, puskesmas are 9,993, spread over at least 1 (one) puskesmas in each district [1].

The puskesmas is a First Level Health Facility (FKTP) as the frontline in efforts to prevent and control the number of Covid-19 cases by anticipating, detecting, responding to events by implementing 3T (tracing, testing, treatment) and vaccinating. Utilization of resources effectively and efficiently can overcome the transmission of Covid-19 for individuals, families, and communities [4,33]. Puskesmas must carry out various efforts to realize optimal public health status, among others, by providing health services. The Covid-19 pandemic period resulted in changes to health services carried out at the puskesmas [5].

Puskesmas have roles and functions that aim to improve the health status of the community and provide integrated health services in all promotive, preventive, and curative activities [6]. However, at this time, the puskesmas are still underutilized by the community. A previous study showed that 53 of the 90 respondents (59\%) still did not use the services at the puskesmas. The lack of interest in using services at the puskesmas is related to several factors: age, gender, knowledge, education, income, occupation, distance, time, and responsiveness of health workers to health needs such as other external factors influences [7]. One study stated that the utilization of services was influenced by several factors, including the lack of facilities or equipment for the puskesmas, accessibility, attitude of officers, public awareness, lack of public interest due to low income [8].

The coverage of the Gading Cempaka area includes the Puskesmas Lingkar Barat, Sidomulyo, and Jalan Gedang. Gading Cempaka District is the district with the highest number of Covid-19 cases, so for the prevention and control of Covid-19, it is necessary to have optimal utilization of the public health center, including puskesmas. Based on this background, researchers are interested in researching the use of puskesmas to prevent Covid-19 in Bengkulu City, which aims to determine the variables related to the utilization of puskesmas in Bengkulu City.

\section{Materials and Method}

This research was quantitative research with a cross-sectional study and was conducted in March-August 2021. The population was the entire Bengkulu City community, with a sample of 110 respondents in the Gading Cempaka District, Bengkulu City. Collecting data using primary data by distributing questionnaires to respondents containing questions based on the variables studied, such as age (young $=40$ years, older $>40$ years), gender, education (low education $=$ no school-junior high school and education height $=$ high school-college), knowledge, occupation, income (Provincial Minimum Wage), distance (near $=500$ meters and far $=>500$ meters) and family support). Sample selection used was a random sampling technique. Data were analyzed univariate, bivariate, and multivariate using SPSS 16 software.

\section{Results and Discussion \\ 3.1. Results}

\subsubsection{Univariate Analysis Results}

Based on Table 1, it can be determined that from 110 respondents, as many as 86 people $(78.2 \%)$ are women, with the majority were young age group of 67 people $(60.9 \%)$, the education level of most respondents was higher education as many as 73 people (66.4\%). Seventy-three people (66.4\%) had a settled job. Most respondents' income was <UMP, which was 79 people (71.8).

Based on Table 2, the results showed that 88 people (80\%) had used the puskesmas. The distance from the house to the health center was quite close to 86 people $(78.2 \%)$. Respondents who had good knowledge were 62 people $(56.4 \%)$. As many as 80 people $(72.7 \%)$ received family support by accompanying the respondent when he was sick and suggesting going to the puskesmas for treatment. More details can be seen in Table 2. 
Table 1. Frequency Distribution of Respondents' Characteristics

\begin{tabular}{|c|c|c|}
\hline Characteristics & $\mathbf{n}$ & $\%$ \\
\hline \multicolumn{3}{|l|}{ Gender } \\
\hline Male & 24 & 21.8 \\
\hline Female & 86 & 78.2 \\
\hline \multicolumn{3}{|l|}{ Age } \\
\hline Old & 43 & 39.1 \\
\hline Young & 67 & 60.9 \\
\hline \multicolumn{3}{|l|}{ Level of Education } \\
\hline Low & 37 & 33.6 \\
\hline High & 73 & 66.4 \\
\hline \multicolumn{3}{|l|}{ Occupation } \\
\hline Does not work & 37 & 33.6 \\
\hline Work & 73 & 66.4 \\
\hline \multicolumn{3}{|l|}{ Income } \\
\hline$<$ UMP* $^{*}$ & 79 & 71.8 \\
\hline$\geq$ UMP & 31 & 28.2 \\
\hline
\end{tabular}

Table 2. Distribution of the Frequency of Puskesmas Utilization

\begin{tabular}{ccc}
\hline Distribution & $\mathbf{n}$ & $\%$ \\
\hline Health Center Utilization & & \\
Not Utilizing & 22 & 20 \\
Utilize & 88 & 80 \\
Distance & & \\
Far & 24 & 21.8 \\
Close & 86 & 78.2 \\
Knowledge & & \\
Poor & 48 & 43.6 \\
$\quad$ Good & 62 & 56.4 \\
Family support & & \\
$\quad$ Does not support & 30 & 27.3 \\
Support & 80 & 72.7 \\
\hline
\end{tabular}

\subsubsection{Bivariate Analysis Results}

Based on Table 3, it was found that there was a relationship between age ( $P R=5.278$; $95 \% \mathrm{Cl}=1.456-19.133 ; \mathrm{P}<0.05)$, education $(\mathrm{PR}=0.069 ; 95 \% \mathrm{Cl}=0.009-0.535 ; \mathrm{P}<0.05)$, occupation ( $\mathrm{PR}=0.069 ; 95 \% \mathrm{Cl}=0.009-0.535 ; \mathrm{P}<0.05)$ and income $(\mathrm{PR}=0.294 ; 95 \% \mathrm{Cl}=$ 0.111-0.778; $\mathrm{P}<0.05)$ with the utilization of puskesmas. More details can be seen in Table 3.

\subsubsection{Multivariate Analysis Results}

Based on Table 4, it was found that the variables that influenced the utilization of puskesmas were age (Adj. PR $=20.526 ; 95 \% \mathrm{Cl}=1.452-20.526$; $p$-value $<0.05$ ) and education (Adj. PR $=0.67,95 \% \mathrm{Cl}=0.008-0.528 ; \mathrm{p}$-value $<0.05$ ). More details can be seen in Table 4 . 
Table 3. Bivariate Analysis Results

\begin{tabular}{|c|c|c|c|c|c|c|}
\hline \multirow{3}{*}{ Variables } & \multicolumn{4}{|c|}{ Puskesmas Utilization } & \multirow{3}{*}{$\begin{array}{c}\text { PR } \\
(95 \% \mathrm{Cl})\end{array}$} & \multirow{3}{*}{$\begin{array}{c}P \\
\text { value }\end{array}$} \\
\hline & \multicolumn{2}{|c|}{ Not Utilize } & \multicolumn{2}{|c|}{ Utilize } & & \\
\hline & $\mathbf{n}$ & $\%$ & $\mathbf{n}$ & $\%$ & & \\
\hline \multicolumn{7}{|l|}{ Gender } \\
\hline Male & 8 & 33.3 & 16 & 66.6 & 2.571 & 0.084 \\
\hline Female & 14 & 16.3 & 72 & 83.7 & $0.924-7.158$ & \\
\hline \multicolumn{7}{|l|}{ Age } \\
\hline Old & 3 & 7.0 & 40 & 93,0 & 5.278 & 0.007 \\
\hline Young & 19 & 28.4 & 48 & 71.6 & $1.456-19.133$ & \\
\hline \multicolumn{7}{|l|}{ Level of Education } \\
\hline Low & 1 & 2.7 & 36 & 97.3 & 0.069 & 0.001 \\
\hline High & 21 & 28.8 & 52 & 71.2 & $0.009-0.535$ & \\
\hline \multicolumn{7}{|l|}{ Occupation } \\
\hline Does not work & 1 & 2.7 & 36 & 97.3 & 0.069 & 0.001 \\
\hline Work & 21 & 28.8 & 52 & 71.2 & $0.009-0.535$ & \\
\hline \multicolumn{7}{|l|}{ Income } \\
\hline$<$ UMP & 11 & 13.9 & 68 & 86.1 & 0.294 & 0.017 \\
\hline$\geq$ UMP & 11 & 35.5 & 20 & 64.5 & $0.111-0.778$ & \\
\hline \multicolumn{7}{|l|}{ Knowledge } \\
\hline Lack & 6 & 12.5 & 42 & 87.5 & 0.411 & 0.097 \\
\hline Good & 16 & 25.8 & 46 & 74.2 & $0.147-1.147$ & \\
\hline \multicolumn{7}{|l|}{ Distance } \\
\hline Far & 5 & 20.8 & 19 & 79.2 & 1.068 & 1.000 \\
\hline Close & 17 & 19.8 & 69 & 80.2 & $0.349-3.270$ & \\
\hline \multicolumn{7}{|l|}{ Family support } \\
\hline Does not support & 9 & 30.0 & 21 & 70.0 & 2,209 & \\
\hline Support & 13 & 16.2 & 67 & 83.8 & $0.828-5.892$ & 0.117 \\
\hline
\end{tabular}

Table 4. Multivariate Analysis Results

\begin{tabular}{lcccccc}
\hline Variables & $\mathbf{n}$ & $\%$ & Crude PR & Adjusted PR & $\mathbf{9 5 \%} \mathbf{C l}$ & p-value \\
\hline Age & & & & & & \\
$\quad$ Old & 43 & 39.1 & 1 & 1 & $1.452-$ & \\
$\quad \begin{array}{l}\text { Young } \\
\text { Level of }\end{array}$ & 73 & 60.9 & 5.459 & 20.526 & 20.526 & 0.01 \\
$\begin{array}{l}\text { Education } \\
\quad \text { Low }\end{array}$ & & & & & & \\
$\quad$ High & 73 & 33.6 & 1 & 1 & $0.008-$ & \\
\hline
\end{tabular}

\subsection{Discussion}

The results showed that most of the respondents, as many as 86 people, had used the puskesmas. Aligned with other studies which showed that of the 310 respondents studied, 273 people $(88.1 \%)$ used the puskesmas, and the most respondents had sufficient knowledge of 266 people (85.8\%) [9]. Likewise, with the results of other studies, as many as $69.1 \%$ have utilized health services at the puskesmas [10]. Health is an essential thing that is the right of every individual to want and live a healthy life and take advantage of health services [11]. Based on the results of the study, the variables related to the utilization of the puskesmas were age, education, occupation, and income, while the variables that were not related were gender, knowledge, distance, and family support.

Most respondents who had visited the puskesmas were women. Women visited the puskesmas more than men. The results of data analysis showed that gender was not related to the utilization of the puskesmas. Aligned with a previous study showing that most respondents were 45 women $(60.8 \%)$ [12]. Aligned with the results of another study which showed that respondents, 34 (37.8\%) women, while only eight men used health services [13].

A study found no relationship between gender and the utilization of health services [13]. In line with the results of other studies, the use of puskesmas as "gatekeepers" has no 
relationship with gender ( $p$-value $=0.456$ ) [14]. This is possible because of the existence of health services that require women to take advantage of special health services such as health services for pregnancy and specific diseases [15].

It is clear that most respondents in the young age category ( $\leq 40$ years) use the puskesmas. The result of data analysis shows that the age variable is related to utilization. A person's age takes part in making decisions, in this case, to take advantage of existing health services at the puskesmas. The younger the age, the better the action to use health services at the puskesmas.

In line with the results of other studies, the results obtained that from 34 respondents, 24 people $(38 \%)$ used the puskesmas. This shows that the younger the respondent, the better the positive response to health services at the puskesmas. The age of 16-40 years (young category) is a productive and active period. In contrast to the age included in the old category, they will find it difficult to go to health facilities because of their physical condition, and the distance is too far [16].

The results showed that the respondents who used the puskesmas were respondents with higher education. The results of the bivariate analysis also showed a relationship between education and the utilization of the puskesmas. In line with the study results, as many as eight people (10.8\%) with higher education used health services [12]. Similar to the results of other studies, there is a relationship between education and the utilization of health services. The utilization of health services is influenced by one's education [17].

Knowledge and awareness through the learning process taken during education will result in changes or actions to influence one's decision to be able to take advantage of health services. Education is essential for every individual human being to have broad knowledge and insight and is a field that shapes attitudes, behavior, and actions, both individuals and groups to have a sense of will to move forward [18].

The majority of respondents in this study were those who worked, and most respondents used the puskesmas. The study results concluded that work has a relationship with one's actions to take advantage of the puskesmas. Someone who works but can still take advantage of health services can be an impulse that makes them decide to pay attention to their health during their busy time at work. In line with the results of Erdiwan et al.'s (2020) research showing that most respondents are working as many as 60 respondents (62.5\%), someone who works is more likely to take advantage of health services [17]. Similarly, the results of a study found that the occupation of the head of the family had a significant effect on the utilization of health facilities (p-value <0.1) [19]. This is not in line with the research results, which show that working respondents have difficulty using services at the puskesmas because the service hours coincide with working hours [14].

A person's impetus to utilize health services is from his work, a social factor in the theory of Health System Models [20]. The utilization of health services is influenced by one of the socioeconomic factors, especially the occupation. A person who has a job will earn income to meet his daily needs [12].

Income is all receipts obtained from the work results can be in the form of money or goods from where he works or his results, in the value of money at the prevailing price. The government determines a person's income with provisions following the UMP of the area where he works. Bengkulu Province, according to the Governor's Decree Number T.354.DKKTRAS Year 2020, the determination of the UMP will increase by $0.09 \%$ in 2021 to IDR $2,215,000.00$. If the receipt of wages received is less than what is stipulated, it means that the income received is categorized as still less than the specified provisions [21].

The results showed that respondents who have income <UMP more use the puskesmas. The bivariate analysis results show a relationship between income and utilization of the Puskesmas to prevent Covid-19 in the city of Bengkulu. In line with a research result, the utilization of puskesmas in UPTD Puskesmas Langara, West Wawoni District, Konawe Regency is closely related to income [6].

The results of the research by Napirah Ryman et al. (2016) regarding income have a relationship with the utilization of health services in the working area of the Puskesmas Tambarana, Poso Pesisir Utara District, Poso Regency. Respondents with low incomes still use health services. Income contributes significantly to the utilization of health services. People who have the cost will take advantage of health services [22]. People realize that health is essential and must be maintained. Adequate income levels can provide a greater possibility of using health facilities to carry out self-examinations and take medicine [6]. 
The results of this study were primarily respondents with good knowledge who visited the puskesmas a lot. The results of the bivariate analysis showed a relationship between knowledge and the utilization of the puskesmas. The knowledge in this study was the respondent's knowledge about the puskesmas in preventing Covid-19, sort of the main tasks, functions, benefits, the role of the puskesmas, and the efforts of the puskesmas in preventing Covid-19. Respondents gave correct answers about puskesmas.

In this study, some people with lack knowledge still uses the puskesmas. A person's knowledge can be influenced by other factors: information about health services at the puskesmas. The more a person gets information, the more knowledge he has. Respondents felt that at the puskesmas, they got the health services they needed and could indeed use the health services at the puskesmas.

In line with a research result, it shows that education does not relate to the utilization of services at the Puskesmas Kagok $(p=0.920)$. Respondents who use health services with good knowledge are as many as 25 respondents (23.6\%) [23]. In line with the results of other studies, it is known that the utilization of health services at the puskesmas is not related to the knowledge of BPJS participants [18].

Respondents' knowledge can be influenced by many other factors, such as the respondent's experience in obtaining health services, facilities, and information about Puskesmas. Respondents with less knowledge do not want to use health services [23]. The learning process that occurs in a person can increase a person's knowledge. The formation of one's actions can be formed from knowledge [24]. Knowledge can be obtained from the results of knowing into someone's experience that comes from sensing a particular object. Actions on what he gets from the senses are seeing, smelling, hearing, feeling with the tongue, and touching with the skin [20].

This study indicated that most respondents resided quite far from the puskesmas ( $>500$ meters). Respondents whose houses were close to the puskesmas are more likely to use the health services in the puskesmas. The closer the house is to the puskesmas, the greater the number of people visiting the puskesmas. Meanwhile, the farther the house was to the puskesmas, the smaller the number of visits.

In this study, respondents showed that those who lived far from the puskesmas still used health services at the puskesmas because they felt that access was easier to reach. The respondents were BPJS participants with the use of health services at the puskesmas. Distance is one factor that affects a person's desire to take advantage of health services, which is determined by distance as a supporting factor. People continue to use health services because people have no other service options. Respondents who lived close to the puskesmas could use health services between 0.180 and 0.420 compared to respondents far from the health center.

In line with the results of other studies, the accessibility of services (distance to health services) is the highest, with 76 people $(67.9 \%)$ with close access. The analysis results showed that accessibility had no relationship with the utilization of health services at the Puskesmas Payakabung $(p=0.275)$ [15]. The government is obliged to provide access to health services with exceptional quality and standards to guarantee all levels of society get benefits because services are critical to ensure aspects of health needs or health services that are very much needed [25].

A health service will be considered satisfactory if the patient's expectations can be met so that the patient's desire arises to return to visit health services. One of them is from the tangible dimension, namely the ease of reaching the location of the puskesmas [26]. In addition, it is necessary to promote service information through electronic media, print media, and the environment, such as cooperation and events to provide expected services [27].

The results showed that respondents who received more support from their families tend to decide to visit the puskesmas. Respondents whose families support them have the opportunity to take advantage of the puskesmas compared to those who do not have family support. The support provided by the family is in the form of accompanying when sick and recommending treatment at the puskesmas. The results of the bivariate analysis have nothing to do with family use of the puskesmas in an effort to prevent Covid-19.

Meanwhile, respondents who do not get family support still use the service because it is easier to use health services at the puskesmas and get health services that are really needed. The utilization of dental health services for pregnant women at the Puskesmas Oesapa in Kupang City was not related to family support $(p<\alpha 0.362)$ [28]. Family support is the main factor that can encourage someone to take advantage of hospital services. The support can help from various aspects such as providing advice, enthusiasm, and motivation, helping to find a way out in terms 
of costs and accompanying treatment at the hospital. All are carried out in the form of maximum effort to heal family members [29].

The results of the multivariate analysis in this study showed that the factors that influenced the utilization of the puskesmas were age and education by the means that a person's education can affect a person's actions deciding to visit the puskesmas when they need a health check. In line with other studies, it is stated that household heads with higher education can utilize health facilities for outpatient treatment $[12,19]$.

Education can affect a person's intellectual power in deciding something, including the utilization of the puskesmas. Lack of education causes intellectual capability to be limited so that their surrounding circumstances still influence their behavior. In contrast, someone with a higher level of education has a broader view of things and is younger to accept new ideas or ways of life [18]. Education affects a person's mindset. The higher a person's education, the needs, and demands for health services will also increase. Everyone will pay attention to aspects under the objects he encounters based on interests, expertise, and past experiences [30]. So that people with higher education are expected to understand the importance of maintaining health [15].

Age is the most dominant factor influencing the utilization of puskesmas. This is aligned with the preliminary study that showed a relationship between age and utilization of health services at puskesmas [31]. The respondent's age affects the utilization of the puskesmas, and this is because the age of 16-40 years (young category) is a productive and active period. In contrast to the age included in the old category, they will find it difficult to go to health facilities because of their physical condition, and the distance is too far [16].

Age is one of the factors that can affect the utilization of health services. Young age groups (children) are more susceptible to disease (diarrhea, respiratory infections), and productive age is more likely to deal with traffic accidents, work accidents, and diseases. Due to lifestyle, as well as relatively older age are very susceptible to chronic diseases (hypertension, coronary heart disease, or cancer) [32].

\section{Conclusion}

Based on the study results, researchers can conclude that the variables that affect the utilization of the puskesmas to prevent Covid-19 are age and education level. It is expected that the puskesmas can maintain and carry out routine activities related to promoting puskesmas health services during the Covid-19 pandemic under existing health protocols and strive to be the first service in preventing Covid-19. Further research is needed for all puskesmas so that the data can be more representative of the utilization of puskesmas.

\section{Declaration}

Acknowledgments: The authors would like to express their gratitude to all parties, especially the research team, to the Ministry of Research, Technology and Higher Education/BRIN for the funding provided and the LPPM of the University of Muhammadiyah Bengkulu, which has facilitated the activities as well as the Puskesmas Lingkar Barat, Puskesmas Jalan Gedang, and Puskesmas Sidomulyo as places for conducting research.

Conflicts of Interest: There is no conflict of interest in this study.

\section{References}

1. Wirawan, G., \& Januraga, P. P. (2021). Correlation of Demographics, Healthcare Availability, and COVID-19 Outcome: Indonesian Ecological Study. Frontiers in public health, 9, 605290. https://doi.org/10.3389/fpubh.2021.605290

2. Aisyah, D. N., Mayadewi, C. A., Diva, H., Kozlakidis, Z., Siswanto, \& Adisasmito, W. (2020). A Spatial-Temporal Description of the SARS-Cov-2 Infections in Indonesia During the First Six Months of Outbreak. PloS one, 15(12), e0243703. https://doi.org/10.1371/journal.pone.0243703

3. Satgas Penanganan Covid-19 Kota Bengkulu. Data mediacenter Bengkulu Covid 2021. Kota Bengkulu; 2021.

4. Benneyan, J. C., White, T., Nehls, N., Yap, T. S., Aronson, M., Sternberg, S., Anderson, T., Goyal, K., Lindenberg, J., Kim, H., Cohen, M., Phillips, R. S., \& Schiff, G. D. (2021). Systems Analysis of a Dedicated Ambulatory Respiratory Unit for Seeing and Ensuring Follow-up of Patients With COVID-19 Symptoms. The Journal of ambulatory care management, 44(4), 293303. https://doi.org/10.1097/JAC.0000000000000390

5. Kotlar, B., Gerson, E., Petrillo, S., Langer, A., \& Tiemeier, H. (2021). The Impact of the COVID- 
19 Pandemic on Maternal and Perinatal Health: A Scoping Review. Reproductive health, 18(1), 10. https://doi.org/10.1186/s12978-021-01070-6

6. Wanat, M., Hoste, M., Gobat, N., Anastasaki, M., Böhmer, F., Chlabicz, S., Colliers, A., Farrell, K., Karkana, M. N., Kinsman, J., Lionis, C., Marcinowicz, L., Reinhardt, K., Skoglund, I., Sundvall, P. D., Vellinga, A., Verheij, T. J., Goossens, H., Butler, C. C., van der Velden, A., ... Tonkin-Crine, S. (2021). Transformation of Primary Care During the COVID-19 Pandemic: Experiences of Healthcare Professionals in Eight European Countries. The British journal of general practice: the journal of the Royal College of General Practitioners, 71(709), e634-e642. https://doi.org/10.3399/BJGP.2020.1112

7. Febriana, A., Mulyono, S., \& Widyatuti, W. (2021). Family Support on Utilization of Adolescent Reproduction Health Service at the Area of Public Health Service (Puskesmas) of Martapura. Enfermeria clinica, $31 \quad$ Suppl 2, S135-S138. https://doi.org/10.1016/j.enfcli.2020.12.008

8. Aizuddin, A. N., Abdul Jabar, S. W., \& Idris, I. B. (2019). Factors Associated with Health Services Financier Among Temporary Sheltered Homeless in Urban Malaysia. BMC public health, 19(Suppl 4), 548. https://doi.org/10.1186/s12889-019-6871-5

9. Abiodun, O., Ovat, F., \& Olu-Abiodun, O. (2019). Provider-Related Predictors of Utilization of University Health Services in Nigeria. Ethiopian journal of health sciences, 29(2), 239-250. https://doi.org/10.4314/ejhs.v29i2.11

10. Chauhan, B. G., \& Jungari, S. (2021). Factors Affecting the Utilization of Maternal and Child Health Care Services in Tribal Dominated Population States of India. International quarterly of community health education, 42(1), 47-56. https://doi.org/10.1177/0272684X20972857

11. Morais, H., Albuquerque, M., Oliveira, R. S., Cazuzu, A., \& Silva, N. (2018). Organizações Sociais da Saúde: Uma Expressão Fenomênica da Privatização da Saúde No Brasil [Social Healthcare Organizations: A Phenomenological Expression of Healthcare Privatization in Brazil]. Cadernos de saude publica, 34(1), e00194916. https://doi.org/10.1590/0102$311 X 00194916$

12. Liu, Y. B., Liu, L., Li, Y. F., \& Chen, Y. L. (2015). Relationship between Health Literacy, HealthRelated Behaviors and Health Status: A Survey of Elderly Chinese. International journal of environmental research and public health, 12(8), 9714-9725. https://doi.org/10.3390/ijerph120809714

13. Curi, D., Figueiredo, A., \& Jamelli, S. R. (2018). Factors Associated with the Utilization of Dental Health Services by the Pediatric Population: An Integrative Review. Ciencia \& saude coletiva, 23(5), 1561-1576. https://doi.org/10.1590/1413-81232018235.20422016

14. Poss-Doering, R., Kunz, A., Pohlmann, S., Hofmann, H., Kiel, M., Winkler, E. C., Ose, D., \& Szecsenyi, J. (2018). Utilizing a Prototype Patient-Controlled Electronic Health Record in Germany: Qualitative Analysis of User-Reported Perceptions and Perspectives. JMIR formative research, 2(2), e10411. https://doi.org/10.2196/10411

15. Nketiah-Amponsah, E., Alhassan, R. K., Ampaw, S., \& Abuosi, A. (2019). Subscribers' Perception of Quality of Services Provided by Ghana's National Health Insurance Scheme What Are the Correlates? BMC health services research, 19(1), 196. https://doi.org/10.1186/s12913-019-4023-3

16. Lee, M. Y., Lee, T. Y., \& Lee, Y. C. (2020). Experiences of Family Resource Utilization Among Taiwanese Parents of Children with Developmental Delay. Journal of pediatric nursing, 53, e204-e210. https://doi.org/10.1016/j.pedn.2020.04.010

17. Roberts, T., Miguel Esponda, G., Krupchanka, D., Shidhaye, R., Patel, V., \& Rathod, S. (2018). Factors Associated with Health Service Utilisation for Common Mental Disorders: A Systematic Review. BMC psychiatry, 18(1), 262. https://doi.org/10.1186/s12888-018-1837-1

18. Patel, M. R., TerHaar, L., Smith, A., Tariq, M., Worthington, K., Hinton, J., \& Lichtenstein, R. (2020). Knowledge of Health Insurance Terms and the Affordable Care Act in Racially and Ethnically Diverse Urban Communities. Journal of immigrant and minority health, 22(3), 456466. https://doi.org/10.1007/s10903-019-00924-3

19. Hadwiger, M., König, H. H., \& Hajek, A. (2019). Determinants of Frequent Attendance of Outpatient Physicians: A Longitudinal Analysis Using the German Socio-Economic Panel (GSOEP). International journal of environmental research and public health, 16(9), 1553. https://doi.org/10.3390/ijerph16091553

20. McGrath C. (2019). Behavioral Sciences in the Promotion of Oral Health. Journal of dental research, 98(13), 1418-1424. https://doi.org/10.1177/0022034519873842

21. Surat Keputusan Gubenur. Upah Minimum Provisni Bengkulu. 2020.

22. Hamada, S., Takahashi, H., Sakata, N., Jeon, B., Mori, T., lijima, K., Yoshie, S., Ishizaki, T., \& 
Tamiya, N. (2019). Household Income Relationship with Health Services Utilization and Healthcare Expenditures in People Aged 75 Years or Older in Japan: A Population-Based Study Using Medical and Long-term Care Insurance Claims Data. Journal of epidemiology, 29(10), 377-383. https://doi.org/10.2188/jea.JE20180055

23. Khaki, J. J., \& Sithole, L. (2019). Factors Associated with the Utilization of Postnatal Care Services Among Malawian Women. Malawi medical journal: the journal of Medical Association of Malawi, 31(1), 2-11. https://doi.org/10.4314/mmj.v31i1.2

24. Devkota, R., Khan, G. M., Alam, K., Sapkota, B., \& Devkota, D. (2017). Impacts of Counseling on Knowledge, Attitude and Practice of Medication Use During Pregnancy. BMC pregnancy and childbirth, 17(1), 131. https://doi.org/10.1186/s12884-017-1316-6

25. Wolfenden, L., Williams, C. M., Kingsland, M., Yoong, S. L., Nathan, N., Sutherland, R., \& Wiggers, J. (2020). Improving the Impact of Public Health Service Delivery ond Research: A Decision Tree to Aid Evidence-Based Public Health Practice and Research. Australian and New Zealand journal of public health, 44(5), 331-332. https://doi.org/10.1111/1753-6405.13023

26. Perera, S., \& Dabney, B. W. (2020). Case Management Service Quality and Patient-Centered Care. Journal of health organization and management, ahead-of-print(ahead-of-print), 10.1108/JHOM-12-2019-0347. https://doi.org/10.1108/JHOM-12-2019-0347

27. Barrios-Ipenza, F., Calvo-Mora, A., Velicia-Martín, F., Criado-García, F., \& Leal-Millán, A. (2020). Patient Satisfaction in the Peruvian Health Services: Validation and Application of the HEALTHQUAL Scale. International journal of environmental research and public health, 17(14), 5111. https://doi.org/10.3390/ijerph17145111

28. Koulidiati, J. L., De Allegri, M., Souares, A., Ouedraogo, S., Hien, H., Robyn, P. J., \& Brenner, S. (2018). Factors Associated with Effective Coverage of Child Health Services in Burkina Faso. Tropical medicine \& international health: TM \& IH, 23(11), 1188-1199. https://doi.org/10.1111/tmi.13140

29. Xu, M., Cheng, M., Gao, X., Wu, H., Ding, M., Zhang, C., Wang, X., Feng, X., Tai, B., Hu, D., Lin, H., Wang, B., Wang, C., Zheng, S., Liu, X., Rong, W., Wang, W., Xu, T., \& Si, Y. (2020). Factors Associated with Oral Health Service Utilization Among Adults and Older Adults in China, 2015-2016. Community dentistry and oral epidemiology, 48(1), 32-41. https://doi.org/10.1111/cdoe.12497

30. Mao, W., Zhang, Y., Xu, L., Miao, Z., Dong, D., \& Tang, S. (2020). Does Health Insurance Impact Health Service Utilization Among Older Adults in Urban China? A Nationwide Cross-Sectional Study. BMC health services research, 20(1), 630. https://doi.org/10.1186/s12913-020-05489-8

31. Kinney, A. R., Graham, J. E., Sharp, J., Hoffman, A., \& Malcolm, M. P. (2021). The Relationship Between Fall Risk and Hospital-Based Therapy Utilization Is Moderated by Demographic Characteristics and Insurance Type. Archives of physical medicine and rehabilitation, 102(6), 1124-1133. https://doi.org/10.1016/j.apmr.2020.12.005

32. Noble, H., \& Barrett, D. (2019). Health Promotion. Evidence-based nursing, 22(1), 14-16. https://doi.org/10.1136/ebnurs-2018-103031

33. Haikal, Ratih Pramitasari, Alvin Maulana Firza Yanuar, Nis Syifa'ur Rahma (2021). The Behaviour of Health Faculty Students Responding to Hoaxes Related Covid-19 on Social Media. Disease Prevention and Public Health Journal, 15 (2). https://doi.org/10.12928/dpphj.v15i2.3992 